\title{
DOGON PRONOMINAL SYSTEMS: THEIR NATURE AND EVOLUTION
}

\author{
Christopher Culy \\ The University of Iowa \\ Koungarma Kodio \\ Patrice Togo \\ D.N.A.F.L.A., Bamako, Mali
}

The Dogon language family has received little attention in the linguistics literature to date. In this paper we examine the binding properties of the pronominal systems of three Dogon languages, Donno So, Toro So, and Togo Kã. We also posit the pronominal system of their common ancestor, and the changes from the common ancestor to the contemporary languages. In doing so, we find two ways in which languages can lose logophoricity: (1) the logophoric pronoun becomes a subject oriented reflexive, and (2) the logophoric pronoun is lost without any reflex. The Dogon languages thus give us insight into the nature of pronominal systems and how they evolve.

\section{Introduction*}

The Dogon language family shows an immense amount of formal variation, in phonology, morphology, and syntax. In this paper we will examine the binding properties of the pronominal systems of three Dogon languages, Donno So (DS), Toro So (TS), and Togo Kã (TK). We will see a variety of properties, many of which are interesting in their own right. However, perhaps the most interesting aspect is that TK seems to be in the process of changing from one type of system

\footnotetext{
* We would like to thank Joan Bresnan, Douro Etienne Kassogué, Peter Sells, Tom Wasow and an anonymous reviewer for helpful comments. Of course, we remain responsible for any errors or omissions.
} 
to another. This change provides evidence for the logophoric hierarchy of Culy [1991].

The last part of the paper will discuss the relationship among these pronominal systems. In particular, we will argue for certain properties that can be ascribed to their common ancestor. In doing so, we show two ways in which logophoric pronouns can change, a subject which has received little attention to date. ${ }^{1}$

\section{Background}

2.1 Dogon. While there are many Dogon languages, ${ }^{2}$ with variation so extreme that some are not even mutually intelligible, the three languages that we will be looking at-DS, TS, and $\mathrm{TK}^{3}-$ seem to be fairly closely related. DS and TS are geographically proximate, while TK is separated from the other two by the Bandiagara Escarpment. TK is the least conservative variety morphologically, while DS is the most conservative variety morphologically. However, DS and TS have been more influenced by Fula than has TK, as evidenced by a number of lexical borrowings.

DS has two major sub-varieties, one spoken in and around the town of Bandiagara, and the other spoken in the smaller villages in the surrounding area. The town variety shows more influence, both lexically and phonologically, from Fula than does the outlying variety. Both of these varieties are almost completely mutually intelligible.

2.2. Binding properties. Dalrymple [1990] argues that the binding properties of any pronoun can be described in terms of combinations of five primitive properties, as shown in (1). 4

(1) Primitive binding properties

a. Subject Binding/Disjointness ([ $\pm \mathrm{sb}])$

The pronoun must be bound to (respectively, disjoint from) a subject.

1 Though there has been some work on how logophoric pronouns arise, e.g. by Hyman [1979], [1981] Voorhoeve [1980], Frajzyngier [1985].

2 See Bertho [1953] and Calame-Griaule [1956] for some discussion of the different varieties.

3 Data on DS are from fieldwork conducted by the first author in 1987-88, unless otherwise noted. Data on TS are from the second author, and data on TK are from the third author, both of whom are native speakers. Descriptions of other aspects of these languages can found in Kervran and Prost [1969, 1986], Calame-Griaule [1968], and Prost [1969], respectively.

4 Dalrymple does not use features to refer to the properties. We do so for typographical convenience. Dalrymple also provides a formalization of the binding properties, which we will not do here, for the sake of brevity. Finally, the Root S Binding property is not relevant for Dogon, so we will say nothing more about it. 
b. Coargument Binding/Disjointness ([ $\pm \mathrm{co}])$

The pronoun must be bound to (respectively, disjoint from) an argument of the same predicate the pronoun is an argument of.

c. Minimal Complete Nucleus Binding

The pronoun must be bound by an argument in the smallest predicate-argument structure containing it and a subject of a tensed clause or possessor distinct from it (i.e., it must be bound in its minimal complete nucleus).

i. Non-subjective $([+\mathrm{mcn}])$

The pronoun must not itself be a subject or possessor.

ii. Subjective $([+\mathrm{mcnS}])$

The pronoun may itself be a subject or possessor.

d. Minimal Finite Domain Binding ([+mfd])

The pronoun must be bound in the smallest finite clause it is contained in.

e. Root S Binding $([+\mathrm{rt}])$

The pronoun must be bound somewhere in the sentence.

English provides a simple illustration of these properties. English reflexive pronouns are generally [+mcn], since they must be bound in the smallest predicate-argument structure containing it and a subject or possessor distinct from it, and they cannot occur as subjects of tensed clauses or possessors. ${ }^{5}$ Some examples are given in (2). Notice in (2c) that even though 'herself' is an argument of 'picture', there is no possessor, so 'herself' is free to be bound by the subject.

(2) English reflexives

a. Pati talked to Leej about herselfi/j

b. Pati said that Lee $\mathrm{j}$ talked about herself $\mathrm{j} / *_{\mathrm{i}}$

c. Pat liked the picture of herself $i$

d. Pati didn't like Leej's picture of herself $j / *_{i}$

On the other hand, English personal pronouns are [-co], since they can't be bound by an argument of the same predicate. Some examples are given in (3). Note that when there is no subject or possessor of the predicate, then either the reflexive pronoun or the personal pronoun is allowed ((2c) vs (3c)).

(3) English personal pronouns
a. Pat $i$ talked to Leej about herk $/ *_{\mathrm{i}} / *_{\mathrm{j}}$
b. Pati said that Leej talked about heri/k/*j
c. Pati liked the picture of heri/j
d. Pati didn't like Leej's picture of heri/k/*j

5 But see Pollard and Sag [1994] for detailed discussion of some exceptional cases. 
One final comment is in order before we move on to Dogon, and that is that Dalrymple deliberately did not discuss logophoric pronouns, which are an important part of Dogon. Logophoric pronouns are pronouns which must have as their antecedents the person whose thoughts, words, or state of mind are being reported. We will not give a detailed analysis of logophoricity, 6 but will use $[+\log ]$ to refer to logophoric pronouns and [-log] to refer to pronouns that cannot have a logophoric antecedent.

\section{Donno So (DS)}

3.1 Personal Pronouns. The personal pronouns are the easiest to describe. DS has first, second, and third person pronouns, distinct in singular and plural. The binding properties of the personal pronouns are also relatively easy to describe. Non-third person pronouns must be disjoint from coarguments (4a-b), but they can corefer with non-coarguments (4c). Note that in (4b) the $m^{\prime}$ is syntactically the possessor of $s o$ 'word', but semantically the argument of 'talk' in just the same way that English myself is the object of the preposition about but semantically the argument of 'talk'. In both cases, they are coarguments of the subject.

(4) Non-third person pronouns

a. As direct object (disjoint from subject) ${ }^{7}$

*mi miñ tebclaa bem
IS IS-OBJ hit
'I hit myself'

b. As oblique (disjoint from indirect object)

* Omar mi le so $m^{\prime}$ m̃ soyyaa be

Omar 1S with word 1S POSS talked PST

'Omar talked to me about myself'

c. As possessor (coreferential with subject)

$\begin{array}{lllll}\text { mi yaana } m & m \tilde{\jmath} & \text { waa } & \text { bem } \\ \text { IS wife lS } & \text { POSS saw } & \text { PST-1S } \\ \text { 'I saw my wife' }\end{array}$

6 See Sells [1987] for one such treatment.

7 Numbers used in the gloss of examples correspond to first, second or third person, hence, is indicates first person singular, $3 \mathrm{P}$ third person plural. The following abbreviations are also used:

$\begin{array}{llllll}\text { AG } & \text { Agentive } & \text { OBJ } & \text { Object } & \text { PST } & \text { Past } \\ \text { AUX } & \text { Auxiliary verb } & \text { Pl } & \text { Plural } & \text { REFL } & \text { Reflexive } \\ \text { DF } & \text { Definite (determiner) } & \text { POSS } & \text { Possessive } & \text { SUBJ } & \text { Subject } \\ \text { LOC } & \text { Locative } & \text { PRP } & \text { Present participle } & & \\ \text { LOG } & \text { Logophoric pronoun } & \text { PSP } & \text { Past participle } & & \end{array}$


Third person pronouns are similar to non-third person pronouns, as the examples in (5) show.

(5) Non-third person pronouns

a. As direct object (disjoint from subject)

wo woñ tebelaa be

3S 3S-OBJ hit PST

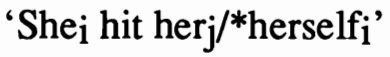

b. As oblique (disjoint from indirect object)

Anta wo le so wo m̃ soyyaa be

Anta 3S with word 3S POSS talked PST

'Antai talked to himj about himi/k/*himselfj'

c. As possessor (coreferential with subject)

Omar yaana wo $\mathrm{m \tilde { \jmath }}$ waa be

3S wife $1 S$ POSS saw PST

'Omari saw hisi/j wife'

The one difference between third person and non-third person pronouns is their properties in logophoric contexts. Third person personal pronouns cannot have as their antecedents the person whose thoughts, words, or state of mind are being reported (6a); non-third person pronouns can (6b).

(6) Personal pronouns in a logophoric environment

a. Third person (disjoint from logophoric subject)

Anta Omar woñ we gi

Anta Omar 3S-OBJ saw said

'Antai said that Omar saw herj/*i'

b. Non-third person

mi Omar miñ we gim

Mi Omar 1S-OBJ saw said-1S

'I said that Omar saw me'

We can summarize the properties of personal pronouns in DS as in (7).

(7) Binding properties of personal pronouns in DS

Non-third person [-co]

Third person $\quad[-\mathrm{co},-\log ]$ 


\subsection{Reflexives}

3.2.1 The description. DS has two reflexive elements, an invariant reflexive pronoun sama, and a periphrastic reflexive, formed from the word for 'head' with a pronominal possessor which agrees in person and number with its antecedent. 8 Some examples are given in (8).

(8) Reflexives in Donno So

a. Simple third person

Anta sama tebelaa be

Anta REFL hit PST

'Anta hit herself'

b. Simple first person
mi sama tebelaa bem
1S REFL hit PST-1S
'I hit myself'

c. Periphrastic third person

$\begin{array}{lll}\text { Anta ku wo mo tebelaa be } & \text { bu } \\ \text { Anta head 3S POSS hit } & \text { PST } \\ \text { "Anta hit herself' } & & \end{array}$

d. Periphrastic first person

mi $\quad k u \quad m^{\prime} \quad m \tilde{s}$ tebelaa bem

1S head 1S POSS hit PST-S

'I hit myself'

Of these two strategies, it seems that the reflexive pronoun is the older one. There are three reasons for thinking this. The first reason is that the pronoun occurs only in the more conservative outlying variety of DS. The periphrastic strategy is found in both the town variety of DS, and in TS.

The second reason for thinking that the pronoun is older is that Fula has the same compound strategy, as the example in (9) shows.

(9) Fula reflexive
Anta fi' ii hoore mum
Anta hit head 3S
'Anta hit herself'

8 See Culy [1993] for detailed discussion of periphrastic reflexives. 
Recall that TS and DS have had more contact with Fula than TK has, and furthermore that the town variety of DS has had more contact with Fula than the outlying variety, especially with Bandiagara acting as the capital of part of the Fula-speaking Toucouleur empire in the 19th century. Finally, speakers of the town variety are much more likely to speak Fula as a second language than speakers of the outlying variety. 9

The third reason for thinking that the reflexive strategy is older is that the pronoun, but not the periphrastic reflexive, has a cognate in TK, as we will see. Thus, it seems plausible that DS has borrowed the compound strategy from Fula, with the borrowing having completely replaced the indigenous reflexive pronoun in the town variety and coexisting with the pronoun in the outlying variety.

3.2.2 The binding properties. The binding properties of the periphrastic reflexive are a little easier to determine than those of the reflexive pronoun. In (10) we see that the periphrastic reflexive cannot be bound outside of its minimal complete nucleus, while (11) shows that it can have a non-subject antecedent. Recall from the discussion of (4b) that the periphrastic reflexive is the syntactic possessor of $s o$ 'word' but the semantic argument of 'talk,' and hence in the same minimal complete nucleus as Anta, which is also an argument of the verb.

(10) Periphrastic reflexive bound in its minimal complete nucleus
Omar Anta $\mathrm{ku}$ wo $\mathrm{m \tilde {s }}$ waa be igi wo
Omar Anta head 3S POSS saw PST know AUX
'Omari knows that Antaj saw herselfj/*himselfi'

(11) Periphrastic reflexive with non-subject antecedent
Anta le $\quad k u \quad$ wo $\mathrm{mo}$ so soyyaa bem
Anta with head 3S POSS word talked PST-1S
'I talked with Anta about herself'

To rule out $[+\mathrm{mfd}]$, we just need to note the ungrammaticality of (12), which contains only one finite verb.

\footnotetext{
9 Who in turn are more likely to speak Bambara as a second language than speakers of the town variety.
} 
(12) Periphrastic reflexive is not $[+\mathrm{mfd}]$
*Omar $[k u$ be $\mathrm{m} \tilde{\mathrm{s}}$ le so
Omar head 3P POSS with word talk-PRP say-PSP

beñ bondaa be

3S-obj call-PSP PST

('Omar called them in order to talk with them')

Although this evidence is all consistent with the periphrastic reflexive being $[+c o]$, the example in (13) shows that the $[+c o]$ account is untenable. The postposition $n \varepsilon$ 'at' has its own predicate, yet the periphrastic reflexive can be bound by the subject, which is not a coargument. Thus, the periphrastic reflexive is [+mcn]: it must have an antecedent in the minimal complete nucleus containing it, and it cannot itself be a subject or possessor.

(13) Periphrastic reflexive not bound by coargument [Kervran 1982:489]

Golu so-go soyyew dyaa yelaa

Golou event-DF talking take come

ku wo m̃ ne wo doaa, yandalan kanaa yaga soyyi head $3 S$ POSS at $3 S$ arrived go over did other talked

'In relating the event, when he arrived at [the part about] himself, Golou passed over it and talked about something else'

The binding properties of the simple reflexive are a little harder to determine. First of all, sama must be bound in its clause, as seen in (14).

(14) Simple reflexive bound in its clause

a. Monoclausal

Anta sama tebelaa be

Anta REFL hit

PST

'Anta hit herself'

b. Biclausal

Omar Anta sama waa be igi wo

Omar Anta REFL saw PST know AUX

'Omar knows that Anta $_{\mathrm{j}}$ saw herself $\mathrm{j}_{\mathrm{j}} /$ 'himself $_{\mathrm{i}}$ ' 
That this restriction is not the $[+\mathrm{mfd}]$ restriction can be seen by the clauseboundedness of the reflexive in (15), which contains only one finite verb, and in which 'Omar' is the understood subject of 'talk'.

(15) Simple reflexive is not [+mfd] (cf. (12))

Omar sama le so soyyezen' giaa beñ bondaa be Omar REFL with word talk-PRP say-PSP 3S-OBJ call-PSP PST 'Omari called them ${ }_{j}$ in order to talk with him $/{ }^{*}{ }^{*}$ them $_{j}$ '

What makes it difficult to determine the binding properties of sama is that we have no examples of it occuring as the object of a simple postposition, 10 and it does not occur in the 'talk to $\mathrm{X}$ about $\mathrm{Y}$ ' construction that we used earlier. The reasons sama does not occur in this construction are slightly involved.

First of all, in (16) we see that sama cannot occur as a possessor. However, this does not seem to be a consequence of the binding properties of sama. Rather, sama seems not to be able to occur with any overt case marking, which the possessor is, as shown by Embree [1993]. In particular, other pronouns must occur with Object case marking (e.g., beñ in (15)), even though it is optional for certain other NPs. However, sama does not occur with Object case marking, as seen in (14b). Since sama cannot occur with case marking, it cannot occur as a postnominal possessor of $s o$ in (16).

(16) Simple reflexive as possessor

a. With semantically non-empty common noun

*wo yaana sama m̃ waa be

3S woman REFL POSS saw PST

' $\mathrm{He}_{\mathrm{i}}$ saw his $\mathrm{s}_{\mathrm{i}}$ wife'

b. With semantically empty so

*mi Anta le so sama m̃ soyyaa bem

1S Anta with word REFL POSS talked PST-1S

'I talked with Anta about herself'

Furthermore, pronouns cannot occur in the prenominal position with so as seen in (17a) (cf. (11)). This rules out sama from occuring in this position, as in (17b).

10 Most postpositions are complex, consisting of the simple postposition ne (cf. (13)), combined with a common noun, the "object" being realized as the possessor of the common noun. 
(17) Pronouns in the prenominal position with so

a. Personal//Non-reflexives

*mi Omar le u so soyyaa bem

1S Omar with $2 S$ word talked PST-1S

'I talked with Omar about you'

b. Simple Reflexive

*mi Omar le sama so soyyaa bem
1S Omar with REFL word talked PST-1S
'I talked with Omar about himself'

Given the the lack of the appropriate structures, we cannot tell if [+sb] is relevant for sama. Given that [+sb] does not play a role in any of the other pronouns or reflexives, we will assume that is not in fact relevant for sama. However, we still do not know whether sama is [+co] or [+mcn].

Finally, third person reflexives are not used in logophoric environments to refer to the logophoric antecedent, as seen in (18a).11 Of course, they can refer to a non-logophoric antecedent in the same clause (18b), and non-third person periphrastic reflexives can have logophoric antecedents in the same clause (18c).

(18) Reflexives in logophoric environments

a. Ungrammatical third person periphrastic reflexive

* Omar inyeme ku wo m̃ samaa bem gi

Omar LOG head 3S POSS congratulated AUX-1S said

'Omar said that he $_{\mathrm{i}}$ congratulated himself $\mathrm{i}_{\mathrm{i}}$

b. Grammatical third person periphrastic reflexive

Omar Anta ku wo mo samaa be gi

Omar Anta head 3S POSS congratulated AUX said

'Omari said that Anta $_{\mathrm{j}}$ congratulated herself $\mathrm{j}^{\prime}$

c. Grammatical non-third person periphrastic reflexive

mi ma ku $m^{\prime} \quad m \tilde{s}$ samaa be gim

1S 1S-SUBJ head 1S POSS congratulated AUX said-1S

'I said that I congratulated myself'

We can summarize the properties of the reflexives in DS as in (19).

11 This isn't quite true, as we'll see in the next section. 
(19) Binding properties of reflexives in DS
Simple
Periphrastic
$[+\mathrm{co}] /[+\mathrm{mcn}],[-\log ]$
non-third person
[+mon]
third person
[+mcn], [-log]

3.3 Logophoric elements. There are two types of logophoric elements: the simple logophoric pronouns and a periphrastic logophoric element, formed just like periphrastic reflexives, but with a logophoric pronoun instead of a personal pronoun. The logophoric pronouns are third person only, both singular and plural. Illustrative examples are in (20).

(20) Basic logophoric facts

a. Singular

Anta inyemeñ $i$ gẽno agiya $g i$

Anta LOG-OBJ child robbed-AG-DF took-3P said

'Anta $a_{i}$ said that they took the child who robbed her'

b. Plural

Anta inyemembe yogo bojen gi

Anta LOG-Pl tomorrow go-1P said

'Anta $a_{i}$ said that they $y_{i+j}$ are going tomorrow'

c. Periphrastic (cf. (18a))

Omar (inyeme) $k u$ inyeme mo samaa bem gi

Omar LOG head LOG POSS congratulated AUX-1S said

'Omari ${ }_{i}$ said that he $e_{i}$ congratulated himself $f_{i}$ '

Simple logophoric pronouns must have antecedents outside of their clause, as the examples in (21) suggest. However, this is a general, cross-linguistic property of logophoric pronouns, 12 so we will ascribe it to the feature $[+\log ]$ rather than one of the other binding features.

(21) Logophoric pronouns with same clause antecedents

a. As Direct Object

*Anta inyeme wa mi bolaa be ma tube Anta LOG to I left AUX Q said

'Anta asked herself if I had left'

12 See Culy [1991] for discussion. 
b. As Possessor
*Anta i
inyeme $m \tilde{\jmath}$
wa mi bolaa be
ma gi
Anta child
POSS to
'Anta asked her child if I had left'

The only relevant feature left is [sb], which the logophoric pronouns are not specified for. As we have seen, they can have subject antecedents. They can also have non-subject antecedents, as seen in (22).

(22) Logophoric pronoun with non-subject antecedent
mi inyeme yogo
bojo Mariam ibura
$\varepsilon g \varepsilon m$
tube
1S LOG tomorrow go Mariam mouth-LOC heard-1S said
'I heard from Mariam that she's going tomorrow'

The periphrastic logophoric elements are [ $+\mathrm{mcn}]$ by virtue of being periphrastic reflexives. Obviously, they are also $[+\log ]$. This means that the periphrastic logophoric elements can occur only when their clausemate antecedent itself is logophoric. 13 A grammatical example is in (20c), while an ungrammatical example is in (23).

(23) Periphrastic logophoric element with non-logophoric antecedent
* Omar Anta ku inyeme
Omar Anta head LOG
bem
gi
'Omar ${ }_{i}$ said that Anta ${ }_{j}$ congratulated himself $f^{\prime}$

We can summarize the properties of the pronominal system of DS as in (24).

(24) Binding properties of the pronominal system of DS

\section{Personal}

\section{Exemplar}

Non-third person $\operatorname{mi}(1 \mathrm{~S})$

Third person

wo $(3 S)$

Reflexive

Simple

Periphrastic

Non-third person

Third person sama

ku m' m̃̃ (1S)

ku wo m̃ (3S)
Binding properties

[-co]

[-co], [-log]

$[+\mathrm{co}] /[+\mathrm{mcn}],[-\log ]$

[tmcn]

[+mcn], [-log]

13 DS is a subject pro drop language, so the logophoric subject could be null. See Culy [ms] for more details. 
Logophoric

Simple

Periphrastic
Exemplar

inyeme(S)

ku inyeme mo(S)
Binding properties

$[+\log ]$

$[+\log ],[+\mathrm{mcn}]$

By gathering the properties together, we can see that the system forms a coherent whole. The logophoric pronoun has its niche, and other obligatory coreference cases are taken care of by the reflexives. The periphrastic reflexive as a construction has the property of $[+\mathrm{mcn}]$, and the rest of the properties of the particular types follow from the internal possessor. Finally, the personal pronouns fill in where obligatory coreference is not possible.

\section{Toro So (TS)}

4.1 Personal Pronouns. As with DS, the personal pronouns are the easiest to describe. TS has first, second, and third person pronouns, distinct in singular and plural, just as DS does. The binding properties of these pronouns are also easy to describe.

Starting with non-third person pronouns, it is not difficult to see that they have no binding properties whatsoever. They don't need antecedents, and neither do they need to be disjoint from other NPs. These properties hold within and across clause boundaries. Examples illustrating these facts are in (25).

(25) Non-third person pronouns

a. No antecedent

Anta mũ ne soaa be

Anta 1S OBJ talked PST

'Anta talked to me'

b. No disjointness within a clause

$m \tilde{u}$ mũ ne soaa be
1S 1S OBJ talked PST
'I talked to myself'

c. No disjointness across clauses

mũ Omar wa mũ sa kejaa be gim

1S Omar SUBJ 1S sister met PST said-1S

'I said that Omar met my sister'

Third person personal pronouns do have one property: they cannot have subject antecedents, either in the clause or not. This is illustrated in (26). 
(26) Third person personal pronouns

a. Disjoint from clausemate subject
Omar wo ne lagaa be
Omar 3S OBJ nit PST
'Omari hit himj/*himselfi'

b. Disjoint from other subject

Omar Anta peju wo ebaa be igi wo Omar Anta sheep 3S bought PST know AUX

'Omar knows that Anda $_{\mathrm{j}}$ has bought her $\mathrm{K} /{ }^{*}$ his $\mathrm{s}_{\mathrm{i} / \mathrm{j}}$ sheep'

They can also have non-subject antecedents, as shown in (27). Thus, third person personal pronouns are simply [-sb].

(27) Third person personal pronoun with non-subject antecedent

Madu Anta wa Omar wo sa iyaa be gi

Madu Anta to Omar 3S sister seen PST said

' $\mathrm{Madu}_{\mathrm{i}}$ said to Anta ${ }_{\mathrm{j}}$ that $\mathrm{Omar}_{\mathrm{k}}$ saw her $\mathrm{j} / \mathrm{m} /{ }^{*}$ his $_{\mathrm{i} / \mathrm{k}}$ sister'

4.2 Reflexives. Like DS, TS has two types of reflexives: simple reflexives uno ' $b e$ ', and the same periphrastic reflexive construction as DS. However, TS has no logophoric pronouns. ${ }^{14}$ While the periphrastic reflexives in these two languages are similar, the simple reflexives are not.

First, the simple reflexive in DS is invariant and occurs with any person antecedent, while the simple reflexives in TS are third person only, and the two forms are singular and plural. Second, the simple reflexive in DS is clause bound, but the simple reflexive in TS is not. Rather, it can have any appropriate subject as its antecedent. 15 In other words, it is [+sb]. Examples illustrating these properties are in (28).

(28) Simple reflexive as [+sb]

a. Third person only

$\begin{array}{lll}m u \tilde{u} \text { uno ne soaa be } & \text { ne } \\ \text { 1S REFL OBJ talked } & \text { PST } \\ \text { 'I talked to myself', }\end{array}$

14 It seems likely that uno is cognate with the logophoric pronoun in DS, inyeme and indeed Calame-Griaule [1968] says that in another dialect of TS, the corresponding form is indeed logophoric. See section 6 for further discussion.

15 Provided, of course, that the subject c-commands the reflexive. 
b. Only subject as antecedent

Anta Omar ne so uno mo soaa be Anta Omar OBJ word REFL POSS talked PST

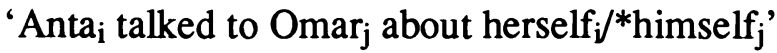

c. Not clause bound (ambiguous)
Mariam Anda wa uno ne lagaa be gi
Mariam Anda SUBJ REFL OBJ hit PST said
'Mariam ${ }_{i}$ said that Anda hit her $_{i}$ himself $_{j}$ '

Note that the latter two examples are sufficient to fix the binding properties of uno. (28c) shows that it is not $[+\mathrm{co}],[+\mathrm{mcn}]$, or $[+\mathrm{mfd}]$, while $(28 \mathrm{~b})$ shows that it is not logophoric, and not simply [+rt], and must be [+sb].

The binding properties of the periphrastic reflexive are also fairly straightforward. It is clause bound, with its antecedent being determined by its internal possessor. Thus, if the posssessor is non-third person, then any c-commanding NP in the same clause with the same person and number can be the antecedent, as seen in (29a). If the possessor is a third person personal pronoun, then the antecedent must not be the subject of the clause (29b), since third person personal pronouns are [-sb]. Finally, if the possessor is a simple reflexive, the antecedent must be the subject of the same clause (29c).

(29) Binding properties of the periphrastic reflexive

a. Non-third person pronoun as possessor
$\begin{array}{llllll}u & k u & u & m o & n e & \text { lagaa be }\end{array}$
$2 S$ head 2S POSS OBJ hit PST
'You hit yourself'

b. Third person personal pronoun as possessor

Mariam Omar ne ku wo mo so soaa be

Mariam Omar to head 3S POSS word talked PST

'Mariam ${ }_{\mathrm{i}}$ talked to Omar $_{\mathrm{j}}$ about himself $\mathrm{j}$ /*herself ${ }_{\mathrm{i}}$ '

c. Simple reflexive as possessor

Mariam Omar ne ku uno mo so soaa be
Mariam Omar to head REFL POSS word talked PST
'Mariam ${ }_{\mathrm{i}}$ talked to Omar ${ }_{\mathrm{j}}$ about herself $\mathrm{f}_{\mathrm{i}} /$ hhimself $_{\mathrm{j}}$ '

We can summarize the binding properties of the pronominal system of TS as in (30). 
(30) Summary of TS pronominal system

\begin{tabular}{|c|c|c|}
\hline & Exemplar & Binding properties \\
\hline $\begin{array}{l}\text { Personal } \\
\text { Non-third person } \\
\text { Third person }\end{array}$ & $\begin{array}{l}m u(1 S) \\
\text { wo (3S) }\end{array}$ & $\begin{array}{l}\text { None } \\
{[-\mathrm{sb}]}\end{array}$ \\
\hline $\begin{array}{l}\text { Reflexive } \\
\text { Simple } \\
\text { Periphrastic } \\
\text { Non-third person } \\
\text { Third person personal } \\
\text { Simple reflexive }\end{array}$ & $\begin{array}{l}\text { uno } \\
\text { ku u mo (2S) } \\
\text { ku wo mo(3S) } \\
\text { ku uno mo }\end{array}$ & $\begin{array}{l}{[+\mathrm{sb}]} \\
{[+\mathrm{mcn}]} \\
{[+\mathrm{mcn}],[-\mathrm{sb}]} \\
{[+\mathrm{mcn}],[-\mathrm{sb}]}\end{array}$ \\
\hline
\end{tabular}

As in DS, the system makes a coherent whole. Non-third person pronouns can occur anywhere, while third person personal pronouns are in complementary distribution with the simple reflexive. The periphrastic reflexive overlaps with all of them, with its particular properties being determined by the properties of its internal possessor.

\section{Togo Kã(TK)}

TK has the most complex pronominal system, even though it has the fewest elements. In addition to personal pronouns, TK has a simple reflexive pronoun and a logophoric pronoun, but no periphrastic reflexives.

We have seen how the pronominal systems of DS and TS make sense when seen as a whole, with the different forms filling different "niches." In order to understand the TK system, it will be easiest to start with the logophoric pronouns, move to the reflexive pronouns, and treat the personal pronouns last.

5.1 Logophoric pronouns. The logophoric pronoun in TK is $\varepsilon n \varepsilon(b e)$, probably cognate with the DS logophoric pronoun inyeme. As in DS, it is third person only, and varies in number. That $\varepsilon n \varepsilon$ is logophoric is suggested by the examples in (31). 16

31) Logophoric pronoun

a. Simple clause (ungrammatical)

*Mariam ene ni tine tine

Mariam LOG to word talked

'Mariam talked to herself $_{\mathrm{i}}$ '

16 In all cases considered in this paper, the subordinate clause is tensed. 
b. Logophoric context (grammatical)
Anta Omar wa yogo
ene geju gi

Anta Omar SUBJ tomorrow LOG sees said

'Antai said that Omar will see her ${ }_{i}$ tomorrow'

c. Non-logophoric context (ungrammatical)

Omar Anta ene oe $\pi$ ii wo

Omar Anta LOG saw know AUX

'Omari knows that Anta saw himi'

However, things are not quite as simple as saying that $\varepsilon n \varepsilon i s[+\log ]$. There are logophoric contexts in which $\varepsilon n \varepsilon$ is used in some positions but not others. One such context is illustrated in (32), and another in (33).

32) Non-uniform distribution of $\varepsilon n \varepsilon$ (with 'think')

a. Subject (grammatical)

Anta ene Mariam oe $g e$ sa

Anta [LOG Mariam saw said] has

'Anta $a_{i}$ thinks she i $_{\mathrm{i}}$ saw Mariam'

b. Possessor of Subject (ungrammatical)

* Omar ene nye yei ge sa

Omar [LOG wife left said] has

'Omar ${ }_{i}$ thinks that hisi ${ }_{i}$ wife left'

33) Non-uniform distribution of $\varepsilon n \varepsilon$ (with 'hear')

a. Subject (grammatical)

Anta ene farãsi yaju $\varepsilon g \varepsilon$

Anta [LOG France go] heard

'Anta ${ }_{i}$ heard that she $e_{i}$ will go to France'

b. Object (ungrammatical)

* Omar Anda ene oe $\varepsilon g \varepsilon$

Omar Anda LOG saw heard

'Omari heard that Anda saw himi'

When we test a variety of verbs, we find the results given in (34). 
(34) Patterns of the logophoric pronoun in subordinate clauses

Subject Object/ Possessor of Subject
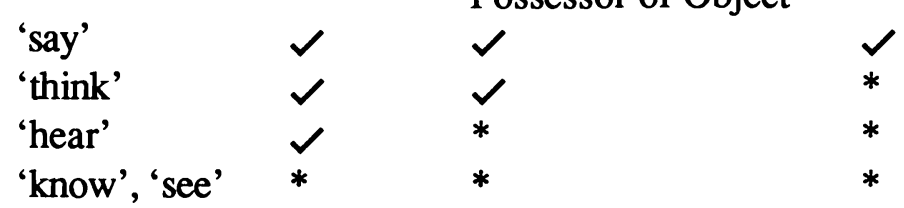

While there might be many ways to think about these facts, the following way seems to be the most illuminating. The verbs with which the logophoric pronoun can occur form a hierarchy, much like that proposed on the basis of crosslinguistic evidence in Culy [To appear]. Thus, we can say that $\varepsilon n \varepsilon$ is [+log], and that it is the logophoric domain which varies according to the verb and the position. The domain for 'say' is everywhere, while the domain for 'think' includes the subject and non-subjects, but not the possessor of subjects. Similarly, the domain for 'hear' only includes subjects. The verbs 'know' and 'see' do not have any logo-phoric domains.

5.2 Reflexives. The simple reflexive is $s \tilde{a}(b e)$, clearly cognate with the simple reflexive sama in DS. While it can have any person antecedents, it only varies in number. The fundamental property of the simple reflexive is that it must have a subject antecedent, as seen in (35a). In addition to being [+sb], the simple reflexive seems to be clause bound, but not necessarily bound to a coargument (35b). There also seem to be no logophoric effects (35c).

(35) Simple reflexive

a. Subject orientation

Mariam Omar ni sã tije tine

Mariam Omar to REFL word talked

'Mariam ${ }_{i}$ talked to Omar ${ }_{j}$ about herself $f_{i} /$ himself $_{j}$ '

b. Clause boundedness, non-coargument antecedent

Omar Anda sã peju ewe $\tilde{i}$ wo

Omar Anda REFL sheep bought know AUX

'Omari knows that Anda ${ }_{j}$ bought his $j_{j * i}$ sheep'

c. No logophoric effects

Omar [sã peju] donyu manuga topo

Omar REFL sheep sell think AUX

'Omar $r_{i}$ thinks that he $e_{i}$ 'll sell his $s_{i}$ sheep' 
However, the situation is a little different when we look at subordinate subjects and their possessors, just as it was with the logophoric pronoun. With certain verbs, the simple reflexive can be the subordinate subject with a matrix argument as its antecedent, while with others it cannot. Similarly, with a different set of verbs, the simple reflexive can be the possessor of the subordinate subject with a matrix argument as its antecedent. Some illustrative examples are given in (3638 ), while a chart of some of the verbs and the behavior of the simple reflexive is given in (39).

(36). Simple reflexive in subordinate subjects (both grammatical)

a. Subordinate subject of 'see' (grammatical)

Omar sã bãdi lagaju oe

Omar [REFL bandit hit] saw

'Omari saw himself $f_{i}$ hit the bandit'

b. Possessor of subordinate subject of 'see' (grammatical)

Omar sã nyẽ $\tilde{1}$ wo lagaju oe

Omar [REFL wife child 3S hit] saw

'Omar saw his wife hit the child'

(37) Simple reflexive in subordinate subjects (one grammatical)

a. Subordinate subject of 'hear' (ungrammatical)

*Anta sã farãsi yaju $\varepsilon g \varepsilon$ lagaju oe

Anta [REFL France go] heard hit] saw

'Anta $a_{i}$ heard that she $e_{i}$ will go to France'

b. Possessor of subordinate subject of 'hear' (grammatical)

Omar sã nỹ̃ Anta ni tine $\varepsilon g \varepsilon$

Omar [REFL wife Anta to talked] heard

'Omari heard that hisi wife talked to Anta'

38) Simple reflexive in subordinate subjects (both ungrammatical)

a. Subordinate subject of 'say' (ungrammatical)

*Anta sã yogo yaju gi

Anta [REFL tomorrow leave] said

'Anta said that she will leave tomorrow'

b. Possessor of subordinate subject of 'say' (ungrammatical)

*Omar sã nye yei gi

Omar [REFL wife left] said

'Omar said that his wife left' 
(39) Patterns of the simple reflexive as and in subordinate subjects

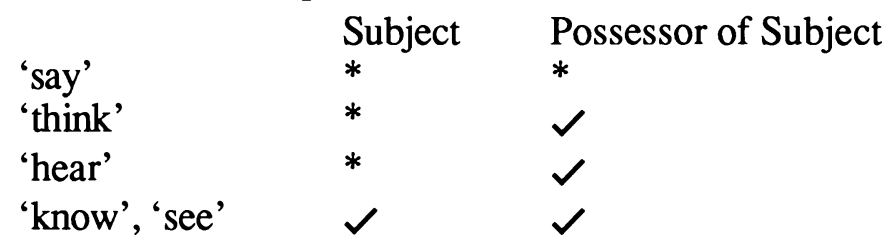

As with the logophoric pronoun there might be many ways to think about these facts. However, in keeping with our view of the logophoric pronoun, we can see that the verbs which disallow the simple reflexive form a hierarchy, similar to that for logophoric pronouns. For example, 'say' disallows the simple reflexive where it allows the logophoric pronoun, and 'hear' allows the simple reflexive where it disallows the the logophoric pronoun. Thus, following the example of the logophoric pronoun, we can say that the subjective (i.e., subject and possessor of subject) form of $s \tilde{a}$ is [+sb] and [-log], with the logophoric domain varying according to the verb and position.

Things are not that simple, of course. When we look at sentences with two levels of embedding, we see that the subjective reflexive pronouns are actually also [ + mcnS], as in (40). We couldn't see this in the earlier examples, since for a subject, the minimal complete nucleus containing it and a distinct subject will be its matrix clause. 17

40) Subjective reflexive pronouns in two levels of embedding 18
Omar [Anta [sã sugo ĩ
wo lagaju] oع] $\varepsilon g \varepsilon$
Omar Anta $3 \mathrm{~S}$ brother child 3S hit
saw heard
'Omar ${ }_{\mathrm{i}}$ heard that Anta $\mathrm{saw}_{\mathrm{j}}$ her $\mathrm{j} /{ }^{*}$ his $\mathrm{i}_{\mathrm{i} / \mathrm{k}}$ brother hit the child'

Since the feature $[+m c n S]$ is relevant for the subjective reflexive, we will assume that it is the feature responsible for the clause-boundedness of the nonsubjective reflexive as well. We can summarize the properties of the logophoric pronoun as in (41).

(41) Properties of TK simple reflexive pronoun

Subjective

(Subject and Possessor of Subject)

[+sb], [+mcnS], [-log]

Logophoric domain varies
Non-subjective

$[+\mathrm{sb}],[+\mathrm{mcnS}]$

17 We have to assume here that for the purposes of $[+\mathrm{mcnS}]$, if the possessor is contained in a subject, then that subject does not qualify as the subject distinct from the possessor.

18 The third person pronoun before the verb lagaju 'hit' is a clitic doubling the real subject $s \tilde{a}$ sugs 'her brother'. 
5.3 Personal Pronouns. Starting with non-third person personal pronouns, it is easy to see that they differ from both their DS and TS counterparts. Unlike TS pronouns, they do have binding properties, but they are not [-co] as in DS. Rather, they seem to be disjoint from subjects in their own clause, but not necessarily from other subjects. Some examples are in (42). To indicate that non-third person personal pronouns are disjoint from a same clause subject, not all subjects, we will combine the features into a complex: $[-\mathrm{sb} \mid+\operatorname{mcnS}] .19,20$

(42) Non-third person personal pronouns

a. Same clause subject antecedent (ungrammatical)

$$
\begin{aligned}
& \text { *eme eme peju donye } \\
& 1 \mathrm{P} \text { 1P sheep sell-Pl } \\
& \text { 'We're selling our sheep' }
\end{aligned}
$$

b. Same clause non-subject antecedent (grammatical)
Omar $\tilde{\mathbf{I}}$ larã tine ma ni tine
Omar 1S sister word 1S-OBJ to spoke
'Omar spoke to me about my sister'

c. Different clause subject antecedent (grammatical)
i Omar wa wo wa $\tilde{i}$ larã kije gi
1S Omar to [3S SUBJ 1S sister met] said
'I said to Omar that he met my sister'

One exception is the postnominal first person singular possessive ma, the only postnominal possessor. It seems to be simply [-co], since it can corefer with a subject in its clause, as seen in (43).

43) Postnominal first person singular possessive

$\begin{array}{lll}\tilde{I} \quad \text { nye ma } & \text { me } \\ 1 \mathrm{~S} \text { wife } 1 \mathrm{~S}-\mathrm{POSS} & \text { saw } \\ \text { 'I saw my wife' } & \end{array}$

Of course, third person personal pronouns are slightly more complicated. Their fundamental property is that they are [-sb], as seen in (44).

\footnotetext{
19 We will justify the use of $[+\mathrm{mcnS}]$ below.

20 The distinction between two features and a complex corresponds to the distinction between two separate binding equations and a single complex binding condition in Dalrymple [1990:139-141]. (Of course, both of these abbreviate sets of equations (p. $164 \mathrm{ff}$.)).
} 
(44) Third person personal pronouns

Mariam Omar ni wo tine tine

Mariam Omar to 3S word spoke

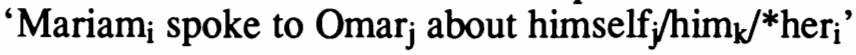

However, like the non-third person pronouns, if the pronoun is not a Subject or Possessor of Subject, then this restriction is limited to the clause containing the pronoun and a subject. Outside of this clause, the pronoun can have a subject antecedent (45). Since the object pronoun can have an antecedent outside of the minimal finite clause containing it, and it can be a possessor we can tell that its restriction is $[+\mathrm{mcnS}]$.

45) Third person non-subjective personal pronouns

Omar [Anta wo oe] $\pi$ iा wo

Omar Anta 3S saw know AUX

'Omar knows that Anta $_{\mathrm{j}}$ saw himi/k'

As with the subjective reflexive pronoun, we need to look at more than one level of embedding to determine whether there is a restriction. The example in (46) demonstrates that the subjective pronouns have the same restriction as the non-subjective ones, namely [+mcnS].

(46) Third person non-subjective personal pronouns in two levels of embedding

Omar [Anta [Wo sugo i wo lagaju] oc] $\varepsilon g \varepsilon$

Omar Anta 3S brother child 3S hit saw heard

'Omar $\mathrm{i}_{\mathrm{i}}$ heard that Anta $\mathrm{j}_{\mathrm{j}}$ saw his $\mathrm{i} / \mathrm{k} /$ *her $_{\mathrm{j}}$ brother hit the child'

As we might expect by now, there is an added wrinkle, namely that of logophoricity. When a third person pronoun is outside the minimal nucleus containing it and a subject, it still cannot have the matrix subject as its antecedent, as we would expect. Examples are in (47), while the patterns are given in (48).

(47) Ungrammatical matrix subject antecedent

a. With a non-subjective pronoun

Omar [Anta wo ni tine gi

Omar Anta LOG to talk said

'Anta ${ }_{i}$ said that Omar $r_{j}$ talked to her $r_{k / * i / * j}$ '

b. With a subjective pronoun

Anta Mariam wa wo Bamako ye $\pi$ wo gi Anta Mariam SUBJ 3S Bamako went know AUX said 'Anta ${ }_{i}$ said that Mariam ${ }_{j}$ knows that $s e_{k / * i / * j}$ went to Bamako' 
(48) Patterns of the third person personal pronouns outside of minimal complete nucleus containing them and a subject

\begin{tabular}{|c|c|c|c|c|}
\hline & $\neq \mathrm{Su}_{\text {matrix }}$ & and & $\neq \mathrm{Su}$ & $\not \mathrm{Su}_{\text {matrix }}$ \\
\hline & $\neq \mathrm{Su}_{\text {matrix }}$ & and & $\neq \mathrm{Su}$ & $\checkmark$ \\
\hline 'know', 'see' & $\begin{array}{l}\neq \mathrm{Su}_{\text {matrix }} \\
\neq \mathrm{Su}_{\text {matrix }}\end{array}$ & & & 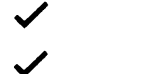 \\
\hline
\end{tabular}

As before, we see a split, so we should analyze the third person personal pronouns as being [-log], with the domain varying by verb and position. Thus, full specification of third person personal pronouns is given in (49).

(49) Binding properties of third person personal pronouns

[-sb I +menS], [-log]

Logophoric domain varies

5.4 Summary of TK. A recurring theme that we have seen in the pronominal system of TK is the hierarchy of logophoric verbs. Let's represent the segments of the hierarchy as in (50), where "D" stands for "Domain".

(50) Segments of the logophoric hierarchy

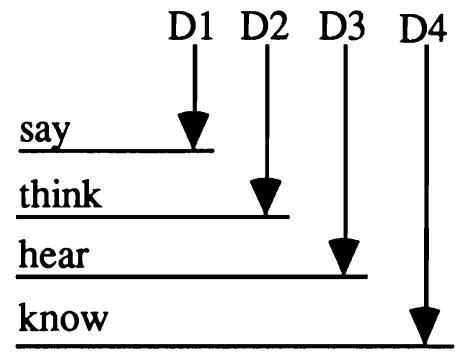

We can now summarize the properties of the pronominal system of TK as in (51). We will use the abbreviations D1-D4 as reminders of which logophoric domain the values $[+\log ]$ and $[-\log ]$ hold in. 
(51) Binding properties of the pronominal system of TK

$S=$ Subject PS=Possessor of subject NS=Non-subject

Personal

Exemplar Binding Properties Domain

Non-third person

First person PSR

Third person $\tilde{1}(1 \mathrm{sg})$
ma
wo $(\mathrm{sg})$

sã (sg)

Reflexive

Logophoric $\varepsilon n \varepsilon(\mathrm{sg})$

$$
\begin{aligned}
& {[-\mathrm{sb} \mid+\mathrm{mcnS}]} \\
& \text { [-co] } \\
& \mathrm{S}=\mathrm{PS}[-\mathrm{sb} \mid+\mathrm{mcnS}], \quad \mathrm{D} 1 \\
& \text { [-log] } \\
& \text { NS } \quad[-\mathrm{sb} \mid+\mathrm{mcnS}], \quad \text { D2 } \\
& \text { [-log] }
\end{aligned}
$$

$\begin{array}{lll}\text { S } & {[+\mathrm{sb}],[+\mathrm{mcnS}],} & \mathrm{D} 3 \\ & {[-\mathrm{log}]} \\ \text { PS } & {[+\mathrm{sb}],[+\mathrm{mcnS}],} & \mathrm{D} 1 \\ & {[-\log ]} \\ \text { NS } & {[+\mathrm{sb}],[+\mathrm{mcnS}]} & \end{array}$

$\begin{array}{lll}\text { S } & {[+\log ]} & \text { D3 } \\ \text { PS } & {[+\log ]} & \text { D1 } \\ \text { NS } & {[+\log ]} & \text { D2 }\end{array}$

The pronominal system of TK presents a serious challenge for linguistic theory. That challenge is how to account for the fact that the logophoric domain seems to vary according to the target position. Usually, a verb either gives rise to a logophoric domain, or it does not. What we have seen in TK is that a logophoric pronoun can be licensed in one position, e.g., as a subject, by a verb, but not in another position, e.g., as the possessor of the subordinate subject. This difference cannot be attributed to the lack of a possessor logophoric pronoun, since other verbs do allow the logophoric pronoun as the possessor of the subordinate subject.

To make matters worse, the logophoric domain varies according to depth of embedding. For example, when the licensing verb is in the immediately higher clause, the domain for non-subjective logophoric pronouns is D2, as we have seen. However, if the licensing verb is two clauses higher, then the domain is D3, as seen in (52). On the other hand, the domain for all subjective logophoric pronouns is D1 in two levels of embedding, as opposed to D3 for subjects and D1 for possessors of subjects in one level of embedding. A comparison of the one level and two level domains is given in (53). 
(52) Domain for non-subjective logophoric pronouns, 2 levels of embedding

a. With 'say' (grammatical)

Madu [Omar wa Ali ene laran oe] $\pi$ ñ wo] gi

Madu Omar SUBJ Ali LOG sister saw know AUX said

' $\mathrm{Madu}_{\mathrm{i}}$ said that $\mathrm{Omar}_{\mathrm{j}}$ knows that $\mathrm{Ali}_{\mathrm{k}}$ saw $_{\text {his }} \mathrm{i}_{\mathrm{i} / \mathrm{j}_{\mathrm{j}} / \mathrm{k}_{\mathrm{k}}}$ sister'

b. With 'think' (grammatical)

Anta [Mariam wa [Hawa ene $\tilde{i}$ wo lagaju] oc] manugi

Anta Mariam SUBJ Hawa LOG child 3S hit saw thinks

'Anta $a_{i}$ thinks that Mariam ${ }_{j}$ saw Hawa $a_{k}$ hit her $\mathrm{i}_{\mathrm{i} / *^{*} /{ }^{* k}}$ child'

c. With 'hear' (grammatical)

Anta [Mariam wa [Hawa $\varepsilon n \varepsilon \tilde{I}$ wo lagaju] oc] $\varepsilon g \varepsilon$

Anta Mariam SUBJ Hawa LOG child 3S hit saw heard

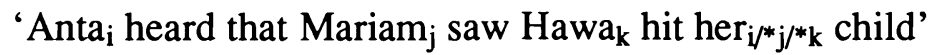

d. With 'know' (ungrammatical)

Madu [Omar wa [Ali ene laran oe] gi] $\pi$ ñ wo

Madu Omar SUBJ Ali LOG sister saw said know AUX

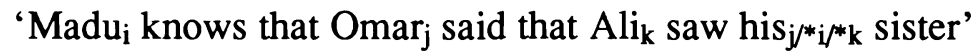

(53) One level and two level domains for logophoric pronouns

$\begin{array}{llll} & S & P S & N S \\ \text { 1 level } & \text { D3 } & \text { D1 } & \text { D2 } \\ \text { 2 level } & \text { D1 } & \text { D1 } & \text { D3 }\end{array}$

No other binding properties change, and indeed they need not. The properties of the simple reflexive are completely circumscribed with one level of embedding. On the other hand, we already had to look at two levels of embedding to determine the properties of the personal pronouns.

\section{Reconstruction}

Given that DS, TS, and TK are relatively closely related, and that their pronouns seem to be cognates, the question arises as to how this situation came about. The natural assumption is that the three languages have a common ancestor, and that the three pronominal systems have evolved from the system of the common ancestor. This account will show two ways in which logophoric systems can lose their logophoricity. While some attention has been paid to how languages acquire 
logophoric pronouns, our study is the first that we are aware of that examines the loss of logophoricity. 21

DS is clearly the most conservative of the languages with respect to morphology, and it seems likely that it is the most conservative with respect to the pronominal systems. While we cannot justify this position absolutely, we will use this assumption to provide a scenario which we think accounts plausibly for the properties of the three contemporary systems.

The easiest property to account for is the periphrastic reflexive. We have already suggested (section 2) that the periphrastic reflexive found in DS and TS is a borrowing from Fula. Since TK lacks a periphrastic reflexive, the common ancestor (henceforth DCA) also lacked a periphrastic reflexive.

The next property to account for is the existence of just two pronominal types in TS (personal and reflexive), as opposed to three in DS and TK (personal, reflexive, and logophoric). First, we see that the simple reflexives in DS and TK are cognate (sama and sã respectively). Second, the simple reflexive in TS seems to be cognate with the logophoric pronouns in DS and TK. 22 As noted above, the corresponding form unu in another dialect of TS is logophoric, according to Calame-Griaule [1968,xxii-xxiii,xxix]. Furthermore, it is significant that the simple reflexive in TS is third person only, just like the logophoric pronouns in DS and TK, and unlike the simple reflexives in those languages, which may be any person.

To sum up what we have so far, DCA had three types of pronoun: personal, simple reflexive, and logophoric. In other words, it was like the country variety of DS, without the periphrastic reflexive. This is illustrated in (54).

54) Pronominal system of Dogon Common Ancestor

Personal

Non-third person

Third person

Reflexive

Simple

Logophoric

Simple
Exemplar

$*_{\text {*mi }}(1 \mathrm{sg})$

$*_{w O}(3 \mathrm{sg})$

*sama

*inyeme (sg)
Binding properties

[-co]

[-co], [-log]

[+co], [-log]

[+log]

If this reconstruction is correct, then we can see how the three languages evolved. DS added the periphrastic reflexive, and is in the process of losing the simple reflexive (recall that it no longer exists in the town dialect).

21 Aside from speculation in Voorhoeve [1980].

22 Though admittedly the relationship is not as clear as with the simple reflexives. 
TS also added the periphrastic reflexive, and lost the simple reflexive. However, the logophoric pronoun has become a subject oriented reflexive. This change can be seen as a generalization of the general tendency for the logophoric pronoun to have subject antecedents. Recall that there are very few environments in which the logophoric pronoun in DS could have a non-subject antecedent (cf. (22)). Becoming a subject oriented reflexive is the first way in which logophoric pronouns can lose their logophoricity.

One further note on TS concerns the dialect of TS in which the change from logophoric pronoun to subject oriented pronoun has not occurred. This dialect also has a periphrastic reflexive, but no simple reflexive. Thus, it seems that the periphrastic reflexive probably was added before the loss of logophoricity.

TK is the most complex case, in that it is in the process of changing. Based on the variation in the domains for logophoric pronouns, it seems that TK is losing the logophoric pronoun, and the simple reflexive is becoming a subject oriented reflexive. If the simple reflexive in DCA was in fact clause bounded, as we have posited, then the change of the simple reflexive is an example of a common type of change in binding properties [Faltz 1985:145]. We might even see the loss of the logophoric pronoun as a consequence of the expansion of the range of possible antecedents of the simple reflexive. Thus, losing the logophoric pronoun with no reflex is the second way in which a language can lose its logophoricity.

We can summarize the changes in the pronominal systems of Dogon from DCA to the contemporary languages as in (55).

55) Changes in Dogon pronouns from DCA to DS, TS, and TK

a. Simple reflexive

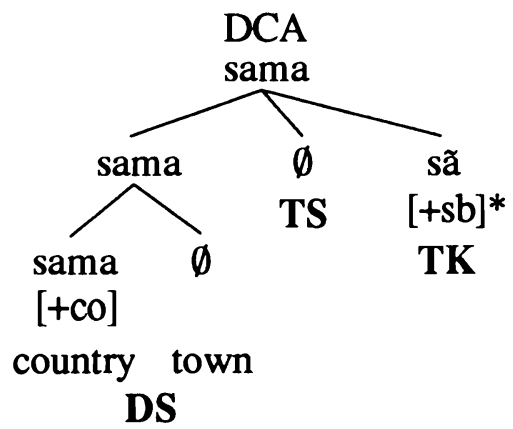

b. Logophoric

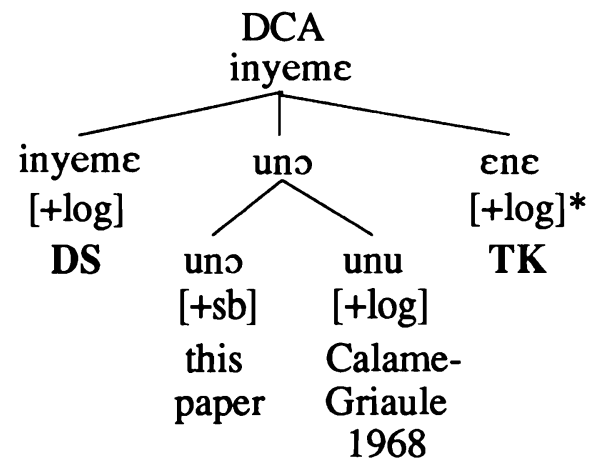

TS 


\section{Conclusion}

The study of Dogon conducted in this paper has had several benefits. First, it is the first detailed study of the pronominal system of any of the Dogon languages, which have received little attention in the literature. We have presented in fairly fine detail the systems of three of the Dogon languages, and compared their properties. It is striking how each system forms a coherent whole, with little overlap in the usage of each form (the notable exception being the simple and periphrastic reflexives in DS). Since languages need not have such nonoverlapping systems-English is a prime example (cf. 2-3)-it is an interesting question as to what types of pronouns lend themselves to non-overlapping systems and why. These are questions that we cannot answer here.

It is also fairly unusual to find a pronominal system in flux. While there has been evidence of change in pronominal systems of other languages, the study of TK here is one of the few in which the change has been documented in progress. It is particularly interesting in that TK seems to be losing its logophoric pronoun, another phenomenon that has not been well attested. The complexity of the change provides a challenge for both synchronic and diachronic theories of language.

Finally, this study is unusual in reconstructing the binding properties of the pronominal system of a common ancestor. While the reconstruction of the pronominal system of DCA cannot be proven in an absolute sense, it does seem to provide a plausible explanation for the properties of the three contemporary Dogon languages. 


\section{REFERENCES}

Bertho, J. 1953. "La place des dialectes dogon de la falaise de Bandiagara parmi les autres groupes linguistiques de la zone soudanaise." Bulletin de l'Institut Français d'Afrique Noire 15:405-441.

Calame-Griaule, Geneviève. 1956. "Les dialectes Dogon.” Africa 26:62-72.

Calame-Griaule, Geneviève. 1968. Dictionnaire Dogon, (Dialecte Toro): Langue et Civilisation. Langues et Littératures de L'Afrique Noire. IV. Paris: Librairie C. Klincksieck.

Culy, Christopher. To appear. "Aspects of logophoric marking." Linguistics 32,5 .

Culy, Christopher. 1993. "Singular anaphors with split antecedents." Paper presented at the Annual Meeting of the LSA, January 1993, Los Angeles.

Culy, Christopher. 1993. "A note on logophoricity in Dogon." Unpublished ms., The University of Iowa.

Dalrymple, Mary Elizabeth. 1990. "Syntactic Constraints on Anaphoric Binding." Ph.D. dissertation, Stanford University.

Embree, Emily. 1993. "The Morpheme ' $m s^{\prime}$ ' and the Dogon Genitive Construction." Paper presented at the 24th Annual Conference on African Linguistics (The Ohio State University).

Faltz, Leonard M. 1985. Reflexivization: A Study in Universal Syntax. New York: Garland Publishing, Inc.

Frajzyngier, Zygmunt. 1985. "Logophoric Systems in Chadic." Journal of African Languages and Linguistics 7: 23-37.

Hyman, Larry M. 1979. "Phonology and Noun Structure." In L.M. Hyman (ed.), Aghem Grammatical Structure. Southern California Occasional Papers in Linguistics 7:1-72. Los Angeles: Department of Linguistics, University of Southern California.

Hyman, Larry M. 1981. Noni Grammatical Structure. Southern California Occasional Papers in Linguistics 9, Los Angeles: Department of Linguistics, University of Southern California. 
Kervran, Marcel, and André Prost. 1969. Les Parlers Dogons I: Donno So. Dakar: Université de Dakar Documents Linguistiques 16.

Kervran, Marcel, and André Prost. 1986. Un Parler Dogon: Le Donno So, Notes de Grammaire. Bandiagara, Mali: Paroisse catholique.

Kervran, Marcel. 1982. Dictionnaire Dogon: Donno So, Région de Bandiagara. Bandiagara, Mali: Paroisse catholique.

Pollard, Carl and Ivan A. Sag. 1994. Head Driven Phrase Structure Grammar. Chicago: CSLI Publications and University of Chicago Press.

Prost, André. 1969. Les Parlers Dogons II: Togo Kã. Dakar: Université de Dakar Documents Linguistiques 17.

Sells, Peter. 1987. “Aspects of Logophoricity." Linguistic Inquiry 18,3: 445-479.

Voorhoeve, Jan. 1980. "Le pronom logophorique et son importance pour la reconstruction du proto-bantou." Sprache und Geschichte in Afrika 2:173-187.

Linguistics Department

University of lowa

Iowa City, Iowa 52242

D.N.F.L.A.

B.P. 62

Bamako

Republic of Mali
[Received December 8, 1993; revision received March 4, 1994; accepted March 10, 1994] 